Susetya, IE. et al. Application Of Coral Transplantation Technology For Coral Reef Ecosystem Problems...

\title{
APPLICATION OF CORAL TRANSPLANTATION TECHNOLOGY FOR CORAL REEF ECOSYSTEM PROBLEMS IN SALAH NAMA ISLAND, BATUBARA REGENCY
}

\author{
Ipanna Enggar Susetya, Desrita and Zulham Apandy Harahap ${ }^{12}$ \\ ${ }^{12}$ Department of Aquatic Resources Management, Agriculture Faculty \\ University of Sumatera Utara \\ Email: ipannaenggar@gmail.com / ipanna@usu.ac.id
}

\begin{abstract}
Coral reefs are one of the typical ecosystems in coastal areas that have ecological and economic value. There are many cases of coral reef damage in Salah Nama Island caused by natural and human factors. Coral reefs damage is mostly caused by human activities such as water pollution, destructive fishing and using of ship anchors. Activity of devotion society aims to provide information and skills to fishermen groups in Salah Nama Island about coral transplantation techniques, as well as conducting coral transplantation activities as one of the efforts to preserve the ecosystem of coral reefs. Based on the description of the problems and objectives of devotion society, the activities that have been done are counseling to the partner fishermen about transplantation and coral benefits in ecosystem, transplantation practice and coral transplantation monitoring.
\end{abstract}

Keywords: coral, transplantation, monitoring, Salah Nama Island

\section{INTRODUCTION}

Tanjung Tiram is a sub-district in Batubara Regency, Province of Sumatera Utara. Most of the area is in the coastal area, and therefore fisherman becomes main livelihood of the population, besides agriculture and plantation. Tanjung Tiram sub-district consists of 20 villages. One of the villages is Suka Jaya Village.

Suka Jaya village is a village located in the coastal area and directly adjacent to the Malacca Strait, most of its inhabitants have livelihoods as fishermen. In general there are 2 (two) categories of fishermen in Indonesia, namely traditional fishermen and modern fishermen. Traditional fishermen are fishermen whose work processes are assisted by using inadequate equipment or still using manual equipment such as using a canoe by rowing with human labor or fishing by using a net. Modern fishermen are fishermen who work with sophisticated equipment such as using boats or fishing by using tools such as trawl (Imron, 2003).

Various studies of fishermen's life generally emphasize on poverty and economic uncertainty, because in various regions most fishermen still use fishing equipment that its use is still relatively traditional, but different from the fishermen in Suka Jaya Village. Fishermen in Suka Jaya Village generally already use the catching equipment that its use is already classified as modern. Using of modern fishing equipment, especially destructive, can cause damage to coastal and marine ecosystems, one of which is coral reef ecosystem.

Coral reef ecosystem is one of the ecosystems that can support the production of fisheries in the oceans. Much evidence shows that the condition of coral reef ecosystems affects fishery production. Fishery commodities whose production is 
Susetya, IE. et al. Application Of Coral Transplantation Technology For Coral Reef Ecosystem Problems...

strongly influenced by the condition of coral reef ecosystems are groupers, snapper, various types of snails and other oysters.

In addition to support the fisheries sector, coral reef ecosystems can also support the tourism sector because coral reef ecosystem is a tourist attraction that is very interested tourists. Much evidence shows that many tourist destinations in the world "sell" coral reef ecosystems as a tourist commodity. Existence of coral reefs can develop tourism potential in a region. Almost all of the coral reef ecosystem-based tourist destination get abundant tourist visits.

Problem faced by both partners (fishermen group) in this devotion activity is decrease fish population. Declining fish population causes the number of catches to decrease which ultimately affects the income of the fishermen. Decline in fish populations, one of the causes due to the damaged condition of coral reef ecosystems. In line with Rondonuwu (2014) states that poor coral reef conditions with low habitat variations lead to reduced presence of reef fish, both species richness (species number), species abundance, and biomass of each species.

Damage of coral reef ecosystems is caused by natural factors (nonanthropogenic) and human activities (anthropogenic). Wave crashing becomes a natural factor that can damage coral reef ecosystem. Indication of destruction by wave power is the number of coral destruction that is lifted from the reef until it is moved into the mangrove ecosystem which is closer to the coastline (Yasser, 2013). Human activities that can damage coral reef ecosystems are the use of destructive fishing gear, the use of ship anchors and pollution.

Lack of public awareness, especially fishermen partners of this devotion about the importance of coral reef ecosystem benefits also become problems and constraints that are being faced. The next problem is the lack of socialization, education and counseling about the coral reef ecosystem in Suka Jaya Village. The importance of coral reef ecosystem role and its relation to fish abundance make ecosystem problem a priority in this activity. A good coral reef ecosystem can increase fish populations, increase the number of tourists thus increasing the income of the community. Through devotion society activities on the application of coral transplantation method it is expected that fishermen, tour guides and local people can understand the importance of coral reef ecosystems and trigger their awareness and concern for the coral reefs so that the ecosystem can be used sustainably for the common welfare. fishermen partners of this devotion to the importance of coral reef ecosystem benefits are also the problems and constraints that are being faced. The next problem is the lack of socialization, education and counseling about the coral reef ecosystem in Suka Jaya Village. The importance of coral reef ecosystem role and its relation to fish abundance make ecosystem problem a priority in this activity. A good coral reef ecosystem can increase fish populations, increase the number of tourists thus increasing the income of the community. Through community service activities on the application of coral transplantation methods, fishermen, tour guides and local communities are expected to understand the importance of coral reef ecosystems and trigger their awareness and concern for coral reefs so that the ecosystem can be used sustainably for the common prosperity.

\section{IMPLEMENTATION METHOD}

Implementation of devotion
society activity is done by several
approaches method, that is, counseling,
education and training of product making
(transplantation shelf), coral transplantation
and coral monitoring. This approach is
expected to increase public awareness,


Susetya, IE. et al. Application Of Coral Transplantation Technology For Coral Reef Ecosystem Problems...

especially fishermen partners about the importance of corals so that always maintain coral reef ecosystem.

\section{Counseling}

The first activity conducted is a counseling about coral transplantation method and the importance of coral reef ecosystem to both fishermen partners and students of Vocational Fisheries School in Batubara. This activity is done by lecture method and discussion. Purpose of this activity is to provide knowledge about coral transplantation method, the importance of coral reef ecosystem so as to foster the spirit to preserve coral reefs to fishermen and students of Vocational Fisheries School in Batubara.

\section{Education and Training on Making of Coral Transplantation Shelf}

Partners are provided with the education and training of transplantation tables including tools and materials used for transplantation, how to make transplant shelfs, how to assemble shelfs, how to plant reefs on shelfs and how to put shelfs in the bottom of the water.

\section{Coral Monitoring}

Coral monitoring was performed about two months after coral transplantation. Purpose of monitoring is to see the success of transplantation, checking the condition of the shelf is upside down or not and cleaning the transplantation shelfs from algae attached and other biofouling organisms.

\section{RESULTS AND DISCUSSION}

The first activity in the devotion society is the submission of proposals to two fishermen partners namely Jasa Laut and Sukma Jaya in May 2017. Partners welcomed and supported this activity because Suka Jaya Village never received socialization and education about coral transplantation. Support of this activity is indicated by providing cooperation letter of cooperation from both partners. Letter of willingness from both partners to be the capital for the submission of a proposal entitled "Application of Coral Transplantation Technology for Coral Reef Ecosystem Problems in Salah Nama Island, Batubara Regency".

\section{Process of Activities}

\section{Counseling}

Counseling and socialization conducted at Vocational School of Fisheries Batubara on 30 August 2017. Participants counseling is two partners of fishermen groups and students of Vocationsl Fisheries School in Batubara. This activity was led by Mrs. Desrita, S.Pi, M. Si as Master of Ceremony (MC) as well as moderator in discussion session. Counseling begins with a speech delivered by the chairman of devotion team, Mrs. Ipanna Enggar Susetya, S.Kel, M.Si. Furthermore, the material exposure on the role of coral reef ecosystem in the waters by Mr. Jogi Arleston, S. STP, MP from the Department of Fisheries Batubara and about coral transplantation techniques by Mr. Zulham Apandy Harahap, S.Kel, M.Si. The next event is a discussion. Two partners and student of Vocational School of Fisheries give question about coral

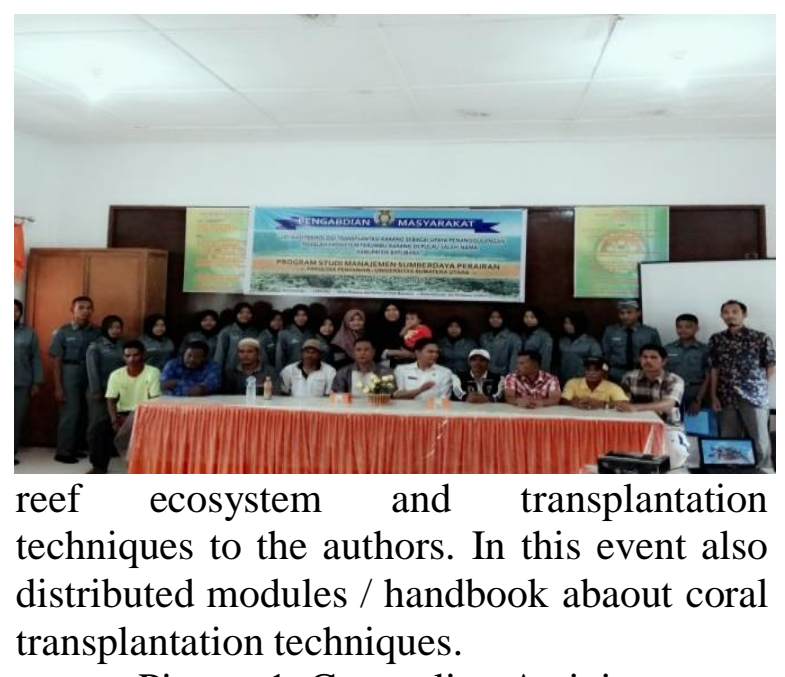

Picture 1. Counseling Activity 
Susetya, IE. et al. Application Of Coral Transplantation Technology For Coral Reef Ecosystem Problems...

\section{Education and Training on Making of Coral Transplantation Shelf}

Subsequent community service activities are education and training on making transplantation shelf. This activity was conducted in Salah Nama Island on the same day as the counseling activity. In this activity the devotion society team works together with Horas Diving Club (HDC). Horas Diving Club is a student activity unit in Departement of Aquatic Resources Management, Agriculture Faculty University of Sumatera Utara.Students from HDC assist in the implementation of training to the fishermen and the process of laying shelves transplant in the waters. The process of laying the transplantation shelves should be done by people who already have a minimum dive certificate A1. Step of coral transplantation training are:

1. Practice of making transplantation shelf by both fishermen partners

This stage is the process of assembly of transplantation shelf that have been prepared from Medan with the condition of the pipe already contains dough of sand and cement that has been dry. When the process of assembling the transplantation shelf took place, also explained about the tools and materials used and how to make it. Measure of transplantation shelf is $0.5 \times 1 \mathrm{~m}$ rectangular shape with high of feet $30 \mathrm{~cm}$ for stick on the bottom of water. Top of shelf stretched with nylon net to place the substrate.

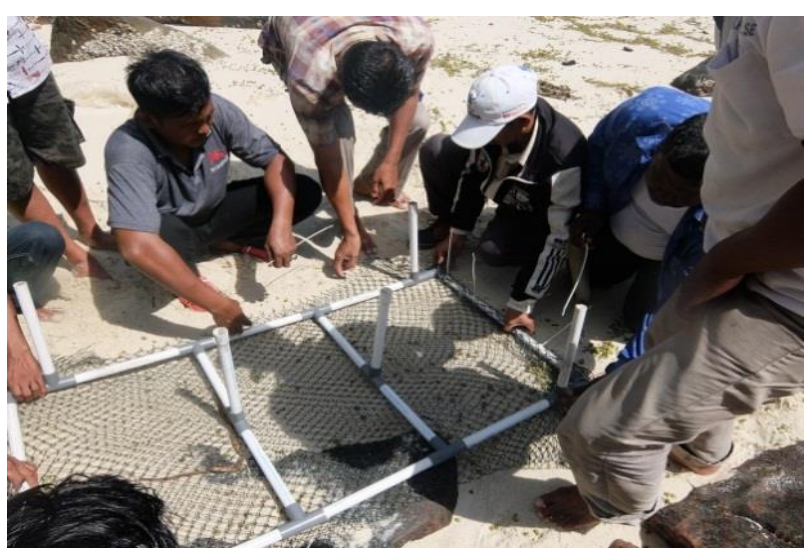

Picture 2. Transplantation shelf assembly

2. Substrate placement

Substrate used in the transplant is concrete (cement) with measure of diameter was $10 \mathrm{~cm}$ and a thickness was $3 \mathrm{~cm}$. Substrate is equipped with a buffer (pipe diameter was $2 \mathrm{~cm}$ and the length was $10 \mathrm{~cm}$ ) in the middle as a place of attachment of transplants and two holes to place the binding of plastic clamps.

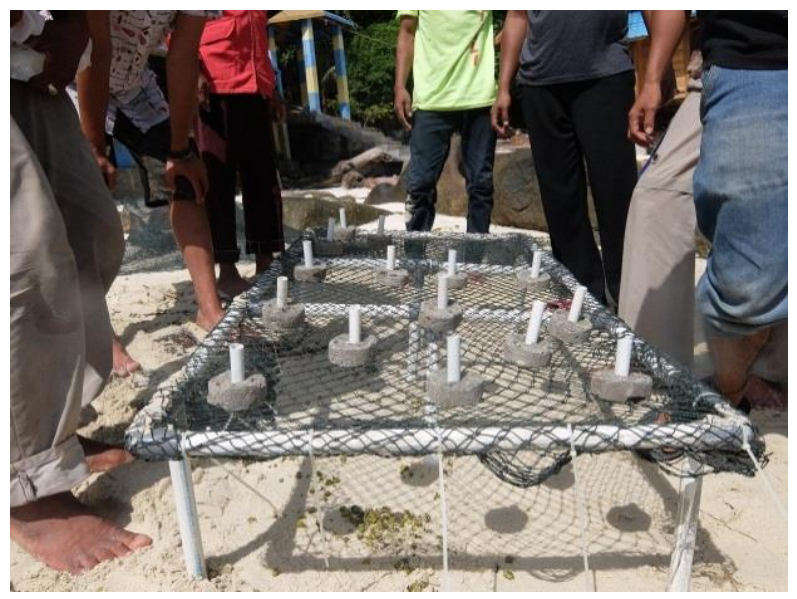

Picture 3. Substrate placement on transplantation shelf

3. Binding of coral seed

Coral seeds taken from the waters of Salah Nama Island. Coral that transplanted on this island are a species of Acropora digitifera. This species of coral selection for transplantation is due to the most common species found in the waters of Salah Nama Island. One of the conditions for coral transplantation is to select the species most commonly found in transplanted waters and should not be taken from other locations. Seedlings are cut and placed in a bucket of seawater to prevent coral reefs from dying. The seeds are then fastened to the substrate. 
Susetya, IE. et al. Application Of Coral Transplantation Technology For Coral Reef Ecosystem Problems...

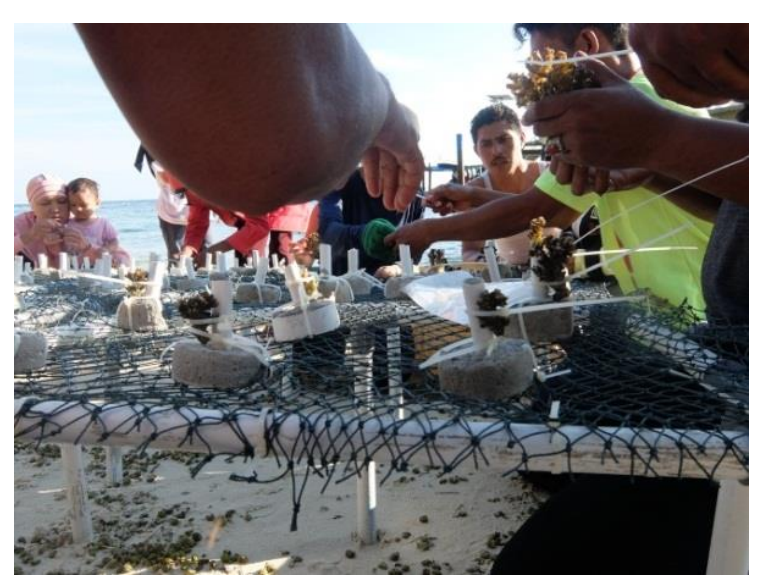

Picture 4. Binding of Coral Seeds

4. Laying of Transplantation Shelf After the binding process is complete, the transplantation shelf are placed at the bottom of water with a depth about $5 \mathrm{~m}$. Transplantation shelves are placed amounted to 5 pieces.

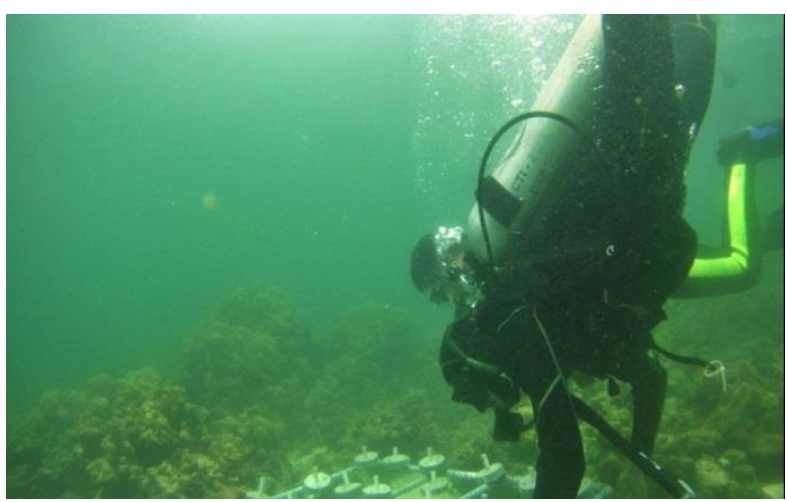

Picture 5. Laying of Transplantation Shelf.

\section{Coral Monitoring}

The most important activity after transplantation is monitoring. Factors that cause of monitoring activities are damage of coral transplantation either because of natural factors that are waves and other biota eaten and because of human activities. Based on monitoring results found one reversed transplantation shelf. This is due to the strong internal currents in the waters of Salah Nama Island. Coral growth can not to be measured because the monitoring time is only two months from the time of planting. Coral growth can be seen at least 6 months after planting. Within one year the corals only grow about $1 \mathrm{~cm}$. Hermanto (2015) states that Acropora formosa coral species has the fastest growth rate of $0.183 \mathrm{~cm} /$ month.

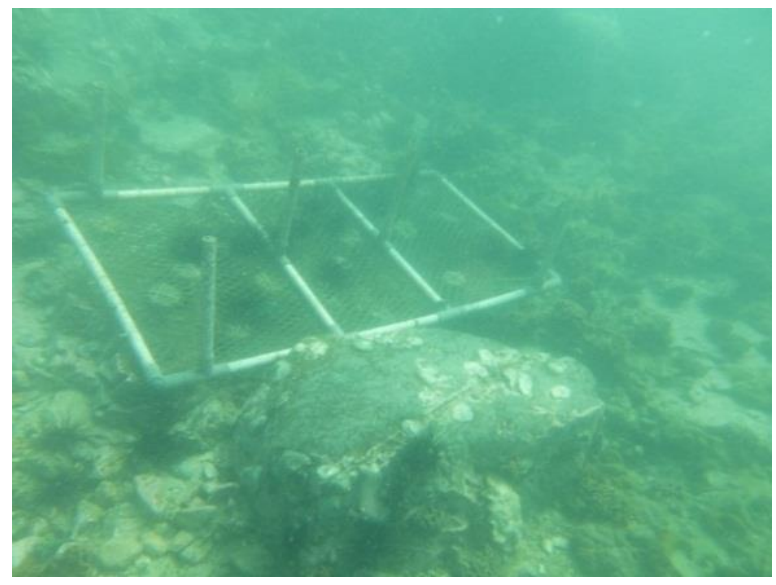

Picture 6. Reversed Transplantation Shelf

\section{CONCLUSIONS AND SUGGESTIONS}

\section{Conclusion}

Devotion society activities that have been done are counseling, coral transplantation and coral monitoring. The result of these activities is the understanding of the community, especially the fishermen about the importance of coral reefs, the skills of fishermen to transplant and the addition of natural rumpon (fish aggregating devices) in Pulau Salah Nama.

\section{Suggestion}

Coral transplantation activities are expected not only to be done on Pulau Salah Nama but in other waters for more coral reefs are maintained ecosystem.

\section{ACKNOWLEDGEMENTS}

This devotion society activity was financially supported by the University of Sumatera Utara through BPPTN funding. Author would like to express the appreciation to our fishermen partners (Jasa Laut and Sukma Jaya), Headmaster Vocational Fisheries of Batubara, Marine and Fisheries Department of Sumatera Utara Province, Fisheries Department of Batubara and Horas Diving Club because of the 
Susetya, IE. et al. Application Of Coral Transplantation Technology For Coral Reef Ecosystem Problems...

helped support in this activity. Special thanks to Syafrida Siregar for preparing anything in Batubara and all parties supporting this activity.

\section{REFERENCES}

Hermanto, B. 2015. Pertumbuhan Fragmen Acropora Formosa Pada Ukuran Yang Berbeda Dengan Metode Transplantasi di Perairan Selat Lembeh. Jurnal Ilmiah Platax Vol. 3:(2), Juli 2015.

Imron, Masyuri. 2003. Pemberdayaan Masyarakat Nelayan. Media Pressindo: Yogyakarta.

Rondonuwu, A.B. 2014. Ikan Karang Di Wilayah Terumbu Karang Kecamatan Maba Kabupaten Halmahera Timur Provinsi Maluku Utara. Jurnal Ilmiah Platax Vol. 2:(1), Januari 2014.

Yasser, M. 2013. Gambaran Sebaran Kondisi Terumbu Karang di Perairan Kecamatan Sangkulirang Dan Sandaran Kabupaten Kutai Timur. Jurnal Ilmu Perikanan Tropis Vol. 18. No. 2, April 2013 